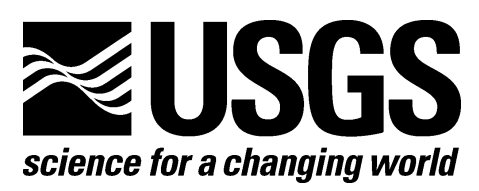

\title{
Weight of Production of Emeralds, Rubies, Sapphires, and Tanzanite from 1995 Through 2005
}

By Thomas R. Yager, W. David Menzie, and Donald W. Olson

Open-File Report 2008-1013 


\section{U.S. Department of the Interior DIRK KEMPTHORNE, Secretary}

\section{U.S. Geological Survey \\ Mark D. Myers, Director}

U.S. Geological Survey, Reston, Virginia: 2008

For product and ordering information:

World Wide Web: http://www.usgs.gov/pubprod

Telephone: 1-888-ASK-USGS

For more information on the USGS - the Federal source for science about the Earth, its natural and living resources, natural hazards, and the environment:

World Wide Web: http://www.usgs.gov

Telephone: 1-888-ASK-USGS

Suggested citation:

Yager, T.R., Menzie, W.D., and Olson, D. W., 2008, Weight of production of emeralds, rubies, sapphires, and tanzanite from 1995 through 2005: U.S. Geological Survey Open-File Report 2008-1013, 9 p., available only online, http://pubs.usgs.gov/of/2008/1013.

Any use of trade, product, or firm names is for descriptive purposes only and does not imply endorsement by the U.S. Government.

Although this report is in the public domain, permission must be secured from the individual copyright owners to reproduce any copyrighted material contained within this report. 


\section{Contents}

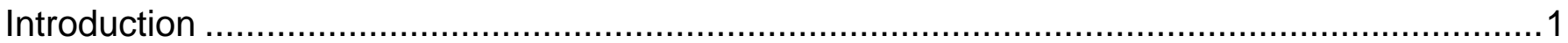

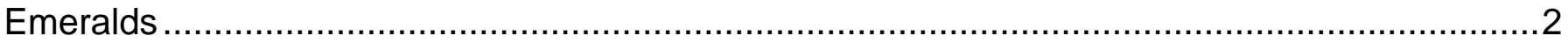

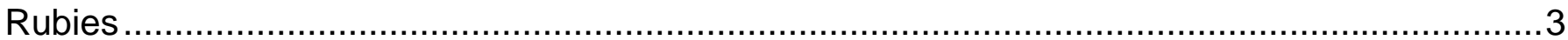

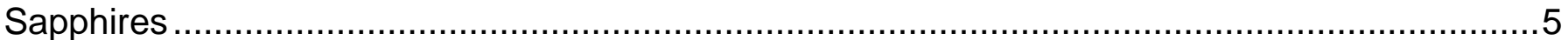

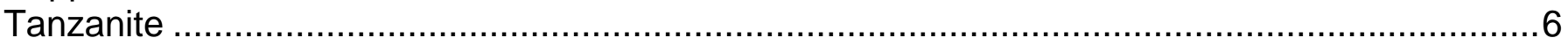

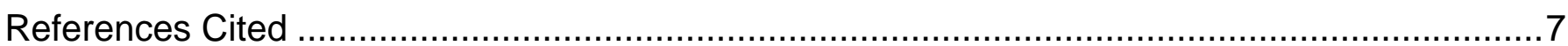

\section{Tables}

Table 1. World Emerald Production $\ldots \ldots \ldots \ldots \ldots \ldots \ldots \ldots \ldots \ldots \ldots \ldots \ldots \ldots$ available in separate file

Table 2. World Ruby Production ....................................... available in separate file

Table 3. World Sapphire Production ..................................... available in separate file

Table 4. World Tanzanite Production .................................available in separate file 


\title{
Weight of Production of Emeralds, Rubies, Sapphires, and Tanzanite from 1995 Through 2005
}

\author{
By Thomas R. Yager, W. David Menzie, and Donald W. Olson
}

\section{Introduction}

U.S. Geological Survey (USGS) historically has not attempted to report comprehensive world production of gemstones on a country basis. This was because estimation of gemstone production is inherently difficult due to the fragmentary nature of the industry, the lack of governmental oversight or reporting in many countries where colored gemstones are mined, and the wide variation in quality between individual gemstones. Unlike diamonds, which, with the exception of the alluvial stones of West Africa, are mainly produced by large international mining companies and evaluated, cut, and marketed through a highly developed pricing structure and complex commercial arrangements, colored gemstones are mainly mined by individuals or small companies and have less developed evaluation and marketing arrangements. The trading centers for colored gems are smaller and less well known than the diamond centers. Colored gemstones, like alluvial diamonds, have the potential to be used to fund civil conflicts and other illegal activities, and because trade in colored gemstones is less organized than that of diamonds, they offer less opportunity for effective regulation of their trade. And, like diamond, until the recent advent of the Kimberley Process no generally accepted estimates of colored gemstone production globally or by producing country have existed. The present paper is a first attempt to develop production statistics for the three precious gems - emeralds, rubies, and sapphires,_and tanzanite, a semi-precious gem. The data consist of the weight of production of each of the gemstones from 1995 through 2005. Preliminary data on the weights of gemstone production were presented as a poster session at the Gemological Institute of America's Gemological Research Conference in San Diego, CA, in 2006, and as a published abstract (Yager, 2006) in an attempt to gather response to the estimates. The USGS continues to welcome information and suggestions that would improve the data presented here.

Information used to make the production estimates presented in this paper include annual USGS Mineral Questionnaires completed by producing countries, data on exports from producing countries, reports from the literature, and company reports.

Comparisons of the weight and the value of production of a type of gemstone between countries may differ considerably. Whereas east African countries dominate the weight production of rubies, Burma (Myanmar) is widely thought to have the highest value of ruby production. Data on the value of gemstone production are even more difficult to estimate than is the weight of production. Value of production is dependent upon both the quality and the sizes of the stones produced. Such data are not readily available and are difficult to estimate; therefore this report does not present tables of values of production. Instead, the report briefly discusses the forms in which 
gemstones are sold, the systems used to value the gemstones, and selected data that illustrate the variability of value of gemstones of a particular type.

\section{Emeralds}

Global emerald production (table 1) increased to about 5,400 kg in 2005 from 4,200 kg in 1995. From 1995 to 2005, Colombia accounted for about 47\% of the world's emerald production by volume; Zambia, about 21\%; Brazil, about 20\%; Russia, about 7\%; and other countries, about $5 \%$. Production shares for individual years are quite variable.

Colombia’s emerald production declined to about 1,600 kg in 2002 from 2,500 kg in 1998. Lower production was attributable to a lack of discovery of significant new resources, antiquated mining methods, falling prices resulting from public concerns over enhancement processes, and a global oversupply. Production recovered in 2003 and 2004, but declined again in 2005. In 1998, the Coscuez Mines accounted for 77\% of Colombia's emerald production; the Muzo Mines, 15\%; and the Chivor Mines, 8\%. In 2005, the La Pita Mines accounted for 60\% of output; Coscuez, 20\%; Chivor, 10\%; and Muzo, 10\%. The quality of production declined with the shift to La Pita from Coscuez and Muzo and increasing mine depths (Lau, 1998a; Austin and others, 2005).

Emerald production increased in Zambia to 1,860 kg in 2002 from $764 \mathrm{~kg}$ in 2001 because of the opening of the Chantete Mine, the expansion of the Grizzly Mine, and the discovery of new deposits in the Musakashi area. By 2004, production had declined to an estimated 1,400 kg because of the shutdown of the Kamakanga Mine and the depletion of the Musakashi deposits discovered in 2002. It is likely that output declined further in 2005 with the closure of the Chantete Mine; the Grizzly and the Kagem Mines accounted for most of Zambia's remaining emerald production (Laurs, 2004; Gemfields Resources Plc, 2005; p. 15-16; Zwaan and others, 2005, p. 120, 123-124, 126).

In Brazil, production declined to less than 500 kilograms per year from 1997 to 1999 from $1,300 \mathrm{~kg}$ in 1996 because of lower output from the Santa Terezinha deposit in Goias State. Production increased to 1,100 kg in 2004 and 1,500 kg in 2005 because of higher output from Carnaiba and Socoto in Bahia, the partial recovery of production from Santa Terezinha and the development of mechanized mining in Minas Gerais State. In Minas Gerais, the Belmont Mine expanded and the Piteiras and Rocha Mines were opened in 2001 and 2005, respectively (Austin and others, 2005; Jewellery News Asia, 2006; Departamento Nacional de Producao Mineral, undated).

In Russia, the Malyshev Mine was reopened in 2001 by ZAO Zelen-Kamen, which was an Irish-Russian joint venture. From 2001 to 2006, the company produced 3,844 kg of emerald by retreating tailings. Tsar Emerald Corp. of Canada purchased ZAO Zelen-Kamen in 2005 and restarted underground mining operations at Malyshev in October 2006. By October 2007, Tsar Emerald planned to produce at a rate of 600 kilograms of emerald per year (ACA Howe International Ltd., 2007).

Other sources of increased emerald production included the Tsa da Glisza emerald project in Canada, the Davdar deposits in China, the Mingora Mine in Pakistan, and the Sandawana Mine in Zimbabwe. Small amounts of emerald were also produced in Afghanistan, Ethiopia, Nigeria, Somalia, Tanzania, and the United States.

Data on the value of uncut emerald are very difficult to obtain. Limited data from Colombian Government sources suggests that the average value of low-quality gemstones from Colombia declined to about \$0.18 per carat in 2001 from \$0.50 per carat in 1996 (Lau, 1998b; 
Ministerio de Minas y Energia, 2002; Rodriguez, undated; Unidad de Planeacion Minero Energetica, 2006). Although this is probably a reasonable indication of the value of most of the gemstones produced in Colombia, it is certainly not a good indication of the value of individual stones. The value of uncut emerald is dependent upon the color, clarity, and carat weight of individual stones. The clarity can be improved by adding oils and resins to fissures in the stones, however treated stones are worth less than untreated stones. Emeralds from Colombia command a premium because of their color and clarity; Colombian emeralds tend to be colored by chromium, and Brazilian emeralds, by vanadium. Uncut emeralds are worked to produce beads, cabochons, or faceted gems.

Price guides are available for cut emeralds and other colored gems. These guides give ranges of price per carat for combinations of ranges of size and quality (Gemworld International, 2007). The quality is determined by the color (hue, saturation, and tone), clarity, and cut of the stone with color playing the major role. Quality is measured as being in one of ten classes. The guide assumes that the stones have been treated with oil to lessen the visibility of cracks in the stone. The value of a one carat extra fine (class 9 or 10) emerald may be several thousand dollars while the value of a one carat lower commercial (class 1 or 2) emerald may be only a several tens of dollars. Prices of stones also vary over time. In the case of emeralds a 2-carat "fine" (class 6-7 or 7-8) emerald can vary dramatically over a period of years. For example, such a stone worth \$5,200/carat in 1995 could have been worth only \$2,000/carat between 2000 and 2002, and worth \$3,300/carat in 2005 (Jewelry Insurance Issues, 2006).

The top five countries of origin for imports of emeralds that were cut but not set in jewelry into the United States ranked in terms of weight for 1996 to 2006 were India 25,068,687 carats, Brazil 20,569,326 carats, Colombia 20, 231, 871 carats, Thailand 4,135,939 carats and Hong Kong $2,639,830$ carats. Total imports were 77,553,062 carats. The average values per carat of imports were India \$12.58, Brazil \$3.18, Colombia \$35.29, Thailand \$16.87, and Hong Kong \$35.72.

\section{Rubies}

Global ruby production (table 2) increased to about 10,000 kg in 2005 from 5,000 kg in 1995, although output has been volatile during this period. Production declined sharply in 2002 before rebounding in 2004. Ruby mining increased in 2005 because of higher output in Kenya, Madagascar, and Burma.

Kenya’s ruby production increased to 5,896 kg in 2000 from about 1,200 kg in 1996, declined to 2,310 kg by 2003 because of a downturn in the world gemstone industry, and rebounded to 5,100 kg in 2005. Rockland Kenya Ltd., which operated the John Saul Mine, was the country’s largest ruby producer.

Tanzania's ruby production declined during the late 1990s because of lower output from the Tunduru deposits. From 1995 to 1999, gemstone mining at Tunduru decreased by between 85\% and $90 \%$. The decline was attributable to a lack of investment in the mines and the discovery of the Ilakaka sapphire deposits, which drew gemstone dealers to Madagascar and left the miners at Tunduru without a market for their gemstones. Production rebounded in 2003 because of new mines opened at Losongonoi and Naende. Large-scale mining started for the first time at Losongonoi in 2005 (Henricus, 1999; Austin and others, 2005).

Madagascar became a major producer of ruby with the discovery of the Andilamena and Vatomandry deposits in 2000. In 2004, mining was inhibited by continued uncertainty about 
ownership of claims, but production increased in 2005 because of the discovery of a new deposit near Andilamena (Leuenberger, 2001; Henricus, 2005).

In Burma, production increased sharply during the late 1990s because of higher output from the Mong Hsu Mines. Ruby from Mong Hsu tended to be produced in greater quantity and lesser quality compared with that from the Mogok Mines. Production subsequently declined to $286 \mathrm{~kg}$ in fiscal year 2002-03 from 1,476 kg in fiscal year 1997-98. By fiscal year 2004-05, however, output had increased to $669 \mathrm{~kg}$ (Austin and others, 2005).

The Nghe An Gem and Gold Company produced hundreds of kilograms of ruby from the Quy Chau deposits in Vietnam from 1996 to 2004. In Malawi, the Chimadzulu Mine was reopened in 2003 and expanded in late 2004. India's ruby mining shut down in Orissa State in 1998. The Jagdalek ruby and sapphire mines in Afghanistan were officially closed in the summer of 2004, although some small amounts of ruby continued to be produced illegally. Cluff Resources Pacific NL mined ruby in Australia. True North Gems started ruby production in Greenland in 2004. Other ruby producers included Brazil, Cambodia, Colombia, Pakistan, Nepal, Russia, Tajikistan, Thailand, the United States, and Zimbabwe (Boehm, 2004; Pham and others, 2004; True North Gems Inc., 2004).

Data on the value of uncut rubies are very difficult to obtain. Limited data from USGS Mineral Questionnaires suggest that the average value of the gemstones from Kenya, Tanzania, and Madagascar is probably between $\$ 0.03$ and $\$ 0.10$ per carat. Although this is probably a reasonable indication of the value of most of the gemstones produced from these countries, it is certainly not a good indication of the value of individual stones; reportedly many African rubies are passed off as Burmese rubies in Rangoon (gold.yabz.com, undated). The value of uncut rubies like uncut diamonds is dependent upon the color, clarity, and carat weight of individual stones. The clarity of stones can be improved by heat treatment; however heat treated stones are worth less than untreated stones. Stones are heat treated because such treatment can cause the absorption of inclusions in stones.

Large uncut and untreated stones of good color and clarity may sell for hundreds or thousands of U.S. dollars per carat. The rubies from certain areas of Burma command a premium because of their color, which is described as pigeon blood red. Uncut rubies are worked to produce beads, cabochons, or faceted gems. Small, uncut rubies suitable for producing cabochons are widely available from rock and mineral establishments. Small (0.5 to 3.0 carats) rubies from Kenya that are suitable for making cabochons are available for from $\$ 0.60$ to $\$ 1.00$ per carat. Similar sized stones from Madagascar that are suitable for cabochons are available for from $\$ 0.60$ to $\$ 1.70$ per carat.

Price guides available for cut rubies also give ranges of price per carat for combinations of ranges of size and quality. The quality is also determined by the color (hue, saturation, and tone), clarity, and cut of the stone with color playing the major role. Like emeralds the quality of rubies in one of ten classes. The guide assumes that the stones have been heat treated. The value of a one carat extra fine (class 9 or 10) ruby may be several thousand dollars while the value of a one carat lower commercial (class 1 or 2 ) ruby may be only a few tens of dollars. Untreated Burmese rubies are evaluated separately and command premium prices. A one carat, untreated Burmese that is rated extra fine (class 9 or 10) may be tens of thousands of dollars (Gemworld International, 2007).

The top five countries of origin for imports of rubies that were cut but not set in jewelry into the United States were ranked in terms of weight for 1996 to 2006 Thailand 25,964,842 carats, India 15,651,789 carats, Hong Kong 2,336,332 carats, Switzerland 417,674 carats, and Germany 352,801 carats. Total imports were 46,679,818 carats. Imports from Burma amounted to 112,304 
carats. The average values per carat of the imports were Thailand \$20, India \$4, Hong Kong \$34, Switzerland \$459, and Germany \$50. The average value per carat of imports from Burma was $\$ 331$.

\section{Sapphires}

Global sapphire production (table 3) is estimated to have declined from about 25,600 kg in 2005 from 32,500 kg in 2000 and 26,900 kg in 1995. Australia was the leading producer of sapphire from 1995 to 1999. Since 2000, Madagascar and Australia have alternated as the world's leading sapphire producer.

Madagascar's production increased to 9,326 kg in 2002 from $115 \mathrm{~kg}$ in 1995 because of the discovery of new deposits. The Ambondromifehy deposit was discovered in 1996 and was mostly replaced by the even more productive deposits at Ilakaka and Sakara in 1998 and 1999. Production declined to 5,890 kg in 2004 and less than 5,000 kg in 2005 because of the depletion of nearsurface resources at Ilakaka and Sakara. New resources were discovered at depths of 26 meters at Ilakaka; the development of these deposits may require mechanical mining (Schwarz, Kanis, and Schmetzer, 2000; Henricus, 2005).

In Australia, production was in a long-term decline because of rising mining costs, marketing problems, lower prices of rough on world markets since the 9/11 terrorist attacks, and droughts that inhibited the development of large-scale mechanized mining at new deposits in Queensland. Production by Great Northern Resources Ltd. (GTN), which was formerly Australia's leading sapphire mining company, declined to 7,000 kg in 1997 from 10,000 kg in 1994. By 2002, GTN's output was less than 2,000 kg. Other producers in Australia included Aussie Sapphire, Coolamon Mining Pty. Ltd., Richardson Mining, and Wilson Gems and Investments (Aboosally, 1998; GTN Resources Ltd., 2002, 2003).

From 2002 to 2005 Sri Lanka produced about 4,000 kilograms per year (kg/yr) of sapphire, which included 3,000 kg/yr of low grade sapphire (geuda), which is suitable for enhancement by heat treatment. Production increased in recent years as the Government opened new areas to gemstone mining (Almeida, 2003; Ellawala, 2006).

China’s sapphire output from mines in Shandong Province amounted to about 3,000 kg in 2005 compared to about $240 \mathrm{~kg}$ in 1994. Substantial amounts of sapphire were cut locally in Shandong. Sapphire was also mined on Hainan Island (AsiaInfo Daily China News, 1994; Austin and others, 2005).

Tanzania's sapphire production declined because of lower production from the Songea, Tunduru, and Umba Valley deposits because of the depletion of near-surface alluvial deposits and competition from Ilakaka in Madagascar (Henricus, 1999; Austin and others, 2005).

Several countries experienced short-lived increases in production during the mid and late 1990s. From 1995 to 1999, large-scale sapphire mine production was revived in the United States; these operations produced about 3,300 kg in Montana. In Vietnam, the Tay Nguyen Mines produced thousands of kilograms of sapphire from 1997 to 2000. Asia Sapphire Ltd. mined substantial amounts of sapphire in northwestern Laos from 1997 to 1999 (Lurie, 1996; Mining Journal, 1997; Jewellery News Asia, 1998; Austin, 2002; Pham and others, 2004).

In Kenya, sapphire mining recovered in 2004 and 2005 from the downturn in the gemstone industry. Malawi's production increased with the expansion of the Chimwadzulu Mine. Output in Burma has declined in recent years. The Mong Hsu Mines were the leading sapphire producers in Burma; small amounts of high-quality sapphire were mined at Nyama. Other producers included 
Brazil, Cambodia, Cameroon, Colombia, Ethiopia, India, Burma, Nepal, Nigeria, Russia, and Somalia (Boehm, 2004; Austin and others, 2005).

Data on the value of uncut sapphire are very difficult to obtain. Limited data from USGS Mineral Questionnaires suggests that the average value of the gemstones from Kenya, Tanzania, and Madagascar is probably less than $\$ 0.01$ per carat. As was the case for ruby, this is probably a reasonable indication of the value of most of the gemstones produced from these countries, it is certainly not a good indication of the value of individual stones. Also like ruby, the value of uncut sapphire is dependent upon the color, clarity, and carat weight of individual stones, and the clarity of stones can be improved by heat treatment; however, heat-treated stones are worth less than untreated stones. Stones are heat treated because such treatment can cause the absorption of inclusions in stones. Some pink sapphires are also heat treated with crushed chrysoberyl to change their color to pinkish-orange. Large uncut and untreated stones of good color and clarity may sell for hundreds or thousands of U.S. dollars per carat. The sapphires from Kashmir command a premium because of their color, which is described as cornflower blue. Padparadscha sapphires, pinkish orange sapphires originally found in Sri Lanka, also command a premium because of their pinkish-orange color. Uncut sapphires are worked to produce beads, cabochons, or faceted gems.

Price guides available for cut sapphires provide ranges of price on a per carat basis for combinations of ranges of size and quality. The quality is also determined by the color (hue, saturation, and tone), clarity, and cut of the stone with color playing the major role. Sapphires display a variety of colors including blue, golden/yellow, green, orange, pink, and purple. Blue sapphire is the most valuable. Blue sapphires from Burma, Kashmir, and the State of Montana (U.S.A.) command a premium price. Like emeralds and rubies, the quality of sapphires is measured as belonging to one of ten classes. The guide assumes that the stones have been heat treated. The value of a one-carat extra fine (class 9 or 10) blue sapphire may be a few thousand dollars while the value of a one-carat lower commercial (class 1 or 2 ) blue sapphire may be only few tens of dollars (Gemworld International, 2007).

The top five countries of origin for imports into the United States of sapphire that was cut but not set in jewelry ranked in terms of weight for 1996 to 2006 were: Thailand 57,114,268 carats, India 10,369,555 carats, Sri Lanka 4,945,934 carts, Hong Kong 2,925,915 carats, and China 917,481 . Total imports of cut sapphires were 80,448,430 carats. Imports of cut sapphire into the United States from Burma were 36,551 carats. The average values per carat of imports were: Thailand \$13.66 per carat, India \$4.76, Sri Lanka \$59.31, Hong Kong \$30.85, and China \$2.65. The average value per carat of cut sapphires from Burma was \$354.28.

\section{Tanzanite}

Tanzanite production (table 4) increased to about 6,500 kg in 2002 from 500 kg in 1995; most of the increase was attributable to artisanal and small scale miners in Blocks B and D at Merelani. Output declined to about 3,400 kg in 2005 because of a lack of new deposits discovered, lower grades of tanzanite, and higher costs in the small-scale mines associated with the increasing depths. Mechanized mining by TanzaniteOne Ltd. in Block C likely to replace artisanal miners (Kondo, 2005; Lucie C. Phillips, President, International Business Initiatives, written com., August 11, 2006). 


\section{References Cited}

Aboosally, Sharm, 1998a, Australian sapphire output drops: Jewellery News Asia, no. 165, May, p. 102-108.

ACA Howe International Ltd., 2007, Competent person's report on the Malyshev Emerald Mine Sverdlosk Oblast for Tsar Emerald Corporation and Nabarro Wells \& Co. Limited: Berkhamsted, United Kingdom, ACA Howe International Ltd., 103 p.

Almeida, Merle, 2003, Sri Lanka—Sapphire uncertainty and political uncertainty: Rapaport NewsBrief, November 7, 1 p.

AsiaInfo Daily China News, 1994, Jewelry street: AsiaInfo Daily China News, July 15, 1 p.

Austin, Gordon, 2002, After the fall: Colored Stone, v. 15, no. 3, March/April, p. 34-35.

Austin, Gordon, Beard, Morgan, Elmore, Mick, Woudenberg, Cara, and Zborowski, Megan, 2005, World mining report: Colored Stone, v. 18, no. 6, November/December, p. 48-55.

Boehm, Edward, 2004, New ruby production from Malawi: Gems \& Gemology, v. 40, no. 1, spring, p. 71.

Departamento Nacional de Producao Mineral, undated, Economia Mineral do Estado de Goiás-37 Anos: Brasilia, Brazil, Departamento Nacional de Producao Mineral, unpaginated.

Ellawala, Chanaka, 2006, Ceylon sapphire-The past, present, and future: Colombo, Sri Lanka, Presentation at 9th Annual General Meeting of the Colombo MBA Alumni Association, July 7, 4 p.

Gemworld International, 2007, The GemGuide—To wholesale gem pricing (Color): Glenview, Illinois, Gemworld International, Inc., 140 p.

Gemfields Resources plc, 2005, Placing of 26,666,667 new ordinary shares and 1,111,111 existing ordinary shares at a price of 45p per share and admission to trading on AIM: London, United Kingdom, Gemfields Resources plc Prospectus, 109 p.

gold.yabz.com, undated, Buying gemstones in Thailand, available on the Web at http://gold.yabz.com/gems.htm accessed 30 November 2007, unpaginated.

GTN Resources Ltd., 2002, Report for the quarter ended 30 June 2002: Sydney, Australia, GTN Resources Ltd., 2 p.

GTN Resources Ltd., 2003, Report for the quarter ended 31 December 2002: Sydney, Australia, GTN Resources Ltd., 2 p.

Henricus, Jennifer, 1999, Extensive reserves remain untapped: Jewellery News Asia, no. 174, April, p. 72, 74. 
Henricus, Jennifer, 2005, As supply decreases, prices set to grow: Jewellery News Asia, no. 248, April, p. 118-128.

Jewellery News Asia, 1998, New setup enhances sapphires: Jewellery News Asia, no. 163, March, p. 68, 72.

Jewellery News Asia, 2006, New emerald mine now largest producer in Brazil: Jewellery News Asia, no. 261, May, p. 78-80.

Jewelry Insurance Issues, 2006, Emeralds; available on the Web at http://www.jcrs.com/newsletters/2006/2006_10.htm, unpaginated.

Kondo, Hamza, 2005, Mining interrupted: Colored Stone, v. 18, no. 4, July/August, p. 44-47.

Lau, Wilson, 1998a, Colombia remains a rich source of emeralds: Jewellery News Asia, no. 180, August, p. 55.

Lau, Wilson, 1998b, Colombian trade, government push for stronger emerald industry: Jewellery News Asia, no. 179, July, p. 43-44.

Laurs, B.M., 2004, Update on several gem localities in Zambia and Malawi: Gems \& Gemology, v. 40, no. 4, winter, p. 347-350.

Leuenberger, Alexander, 2001, The new ruby deposits in eastern Madagascar-Mining and production: Gems \& Gemology, v. 37, no. 2, summer, p. 147-149.

Lurie, Mark, Will new sapphire sources satisfy demand?: Colored Stone, v. 9, no. 2, January/February, p. 38-39.

Mining Journal, 1997, Gem River resumption: Mining Journal, v. 329, no. 8437, July 11, p. 27.

Ministerio de Minas y Energia, 2002, Sector Colombiano de la mineria-Realidad y perspectivas para su desarrollo: Bogota, Colombia, Ministerio de Minas y Energia, 14 p.

Pham, Van L., Hoang, Quang V., Garnier, V., Giuliani, G., Ohnenstetter, D., Lhomme, T., Schwarz, D., Fallick, A.E., Dubessy, J., and Phan Trong, T., 2004, Gem corundum deposits in Vietnam: Journal of Gemmology, v. 29, no. 3, July, p. 129-147.

Rodriguez, L.E., undated, Can the organization of the emerald market be improved in Colombia?: Dundee, United Kingdom, Centre for Energy, Petroleum and Mineral Law and Policy, 14 p.

Schwarz, Dietmar, Kanis, Jan, and Schmetzer, Karl, 2000, Sapphires from Antsiranana Province, Northern Madagascar: Gems \& Gemology, v. 36, no. 3, fall, p. 216-233. 
True North Gems Inc., 2004, True North acquires historic ruby district in Greenland: Vancouver, British Columbia, Canada, True North Gems Inc. press release, April 27, 2 p.

Unidad de Planeacion Minero Energetica, 2006, Boletin estadistico de Minas y Energia 1999-2005: Bogota, Colombia, Unidad de Planeacion Minero Energetica, 124 p.

Yager, T.R., 2006, Recent trends in world gem production: Gems and Gemology, v. 42, no. 3, p.144-145.

Zwaan, J.C., Seifert, A.V., Vrana, Stanislav, Laurs, B.M, Anckar, Bjorn, Simmons, W.B., Falster, A.U., Lustenhouwer, W.J., Muhlmeister, Sam, Koivula, J.I., and Garcia-Guillerminet, Heja, 2005, Emeralds from the Kafuba area, Zambia: Gems \& Gemology, v. 36, no. 3, fall, p. 216-233. 